\title{
The Effect of COVID-19 Pandemic on Pain, Physical Activity, and Anxiety in Individuals with Chronic Musculoskeletal Pain
}

Özgün Araştrrma Research Article
Received/Geliş: 20.11.2020 Accepted/Kabul: 23.12.2020 First Online: 28.09 .2021

Gülşah Özsoy Selçuk Üniversitesi Sağlık Bilimleri Fakültesi 299/1 Alaeddin Keykubat Yerleşkesi 42250 Konya-Türkiye fzt.gulsah@hotmail.com ORCID: 0000-0001-5678-771X

H. Yılmaz 0000-0002-1151-7190 izmir Bozyaka Eğitim ve Araştırma Hastanesi, izmir, Türkiye

i. Özsoy 0000-0001-9048-1116 Selçuk Üniversitesi Sağlık Bilimleri Fakültesi, Fizyoterapi ve Rehabilitasyon Bölümü, Konya, Türkiye

Cite as: Özsoy G, Yılmaz H, Özsoy I. The effect of COVID-19 pandemic on pain, physical activity, and anxiety in individuals with chronic musculoskeletal pain. Tepecik Eğit. ve Araşt. Has Dergisi. 2021;31(3):322-61.

\author{
COVID-19 Pandemisinin Kronik Kas iskelet Ağrısı olan \\ Bireylerde Ağrı, Fiziksel Aktivite ve Anksiyete Üzerindeki \\ Etkisi
}

\author{
Gülşah Özsoy $\oplus^{\oplus}$, Hayriye Yılmaz ${ }^{\oplus}$, İsmail Özsoy®
}

\section{ABSTRACT}

Objective: The COVID-19 pandemic has many features that can potentially trigger and increase chronic pain. The aim of this study was to examine the effects of the pandemic on pain, physical activity and anxiety in individuals with chronic musculoskeletal pain, in both periods of isolation and controlled social life.

Methods: Seventy one individuals with chronic musculoskeletal pain were included in the study. Three different periods (pre-pandemic, isolation and controlled social life) were evaluated and analyzed. Pain intensity (Visual Analogue Scale (VAS)), coronavirus anxiety (Coronavirus Anxiety Scale Short Form (CAS-SF)), and physical activity level (International Physical Activity Questionnaire Short Form (IPAQ-SF)) were evaluated.

Results: The VAS resting score was significantly higher during the isolation compared to the pre-pandemic period $(p=0.002)$. The VAS activity score was significantly higher in the isolation period compared to both pre-pandemic $(p<0.001)$ and controlled social life periods $(p<0.001)$. The lowest IPAQ-SF score $(p<0.001)$ and the longest sitting time $(p<0.001)$ were in the isolation period. The CAS-SF scores were significantly higher in the isolation period compared to the controlled social life period $(p<0.001)$.

Conclusion: While the measures taken during the isolation period had negative impacts on the severity of pain, physical activity and anxiety levels in individuals with chronic musculoskeletal pain, gradual deconfinement in the controlled social life period led to a decrease in pain intensity and anxiety and an increase in physical activity.

Keywords: COVID-19, chronic musculoskeletal pain, anxiety, physical activity

Öz

Amaç: COVID-19 pandemisi, kronik ağrıyı potansiyel olarak tetikleyebilecek ve artırabilecek birçok özelliğe sahiptir. Bu çalışmanın amacı, kronik kas-iskelet sistemi ağrısı olan bireylerde pandeminin hem izolasyon hem de kontrollü sosyal yaşam dönemlerinde ağrı, fiziksel aktivite ve anksiyete üzerindeki etkisini incelemekti.

Yöntem: Çalışmaya kronik kas-iskelet sistemi ağrısı olan 71 kişi dahil edildi. Üç farklı dönem (pandemi öncesi, izolasyon ve kontrollü sosyal yaşam) değerlendirildi ve analiz edildi. Ağrı şiddeti (Görsel Analog Skala (VAS)), koronavirüs anksiyetesi (Koronavirüs Anksiyete Ölçeği Kısa Formu (CAS-SF)) ve fiziksel aktivite düzeyi (Uluslararası Fiziksel Aktivite Anketi Kısa Formu (IPAQ-SF)) değerlendirildi.

Bulgular: VAS istirahat skoru izolasyon döneminde anlamlı olarak COVID-19 öncesine göre yüksekti ( $p=0.002)$. VAS aktivite skoru izolasyon döneminde anlamlı olarak COVID-19 öncesine $(p<0.001)$ ve kontrollü sosyal hayat dönemine $(p<0.001)$ göre yüksekti. Katılımcıların en düşük IPAQ-SF skoru $(p<0.001)$ ve en uzun oturma süresi $(p<0.001)$ izolasyon dönemindeydi. Katılımcıların CAS-SF skoru izolasyon döneminde anlamlı olarak kontrollü sosyal hayat dönemine göre yüksekti ( $p<0.001)$.

Sonuç: COVID-19 pandemisi sürecinde izolasyon dönemindeki alınan önlemler kronik muskuloskeletal ağrılı bireylerde ağrı siddeti, fiziksel aktivite ve anksiyetenin olumsuz etkilenmesine neden olurken kontrollü sosyal hayat dönemi ile birlikte ağrı şiddeti ve anksiyete düzeyinde azalma ve fiziksel aktivitede artış olmuştur.

Anahtar kelimeler: COVID-19, kronik kas-iskelet sistemi ağrısı, anksiyete, fiziksel aktivite (c) Telif hakkı T.C. Sağıı Bakanlığı İmir Tepecik Eğit. ve Araşt. Hastanesi. Logos Tıp Yayıncılık tarafindan yayınlanmaktadır. Bu dergide yayınlanan bütün makaleler Creative Commons Atff-GayriTicari 4.0 Uluslararası Lisansı ile lisanslanmıștır.

(c) Copyright Association of Publication of the T.C. Ministry of Health izmir Tepecik Education and Research Hospital. This journal published by Logos Medical Publishing. Licenced by Creative Commons Attribution-NonCommercial 4.0 International (CC BY) 


\section{INTRODUCTION}

The coronavirus SARSCoV-2 (Severe Acute Respiratory Syndrome-Coronavirus-2), has been globally and rapidly spreading as the infectious COVID-19 disease (1). Many countries have taken measures to prevent the spread of COVID-19 such as social isolation and reordering the priorities of health services ${ }^{(2)}$. This has caused a change in all elective surgical procedures and outpatient medical practices, including pain management services ${ }^{(3)}$. As an undesirable result, patients with chronic pain faced a negative alteration in their routine medical care ${ }^{(4)}$.

The impact of chronic musculoskeletal pain on restricting daily activities and reducing quality of life is well documented (2). Biopsychosocial model provides a solid framework for chronic pain management. This model incorporates a dynamic and versatile interplay between biological, social, and psychological components ${ }^{(5)}$. Genetic factors, physical and/or emotional traumaes, and previous pain experience can predispose an individual to chronic musculoskeletal pain ${ }^{(6)}$. Likewise, organrelated biological variables and psychosocial stresses can also trigger chronic pain ${ }^{(7)}$.

Chronic pain can be triggered and/or increased due to the prolonged stress caused by the COVID19 pandemic (4). Moreover, physical and psychological effects of social isolation and problems in accessing health services are potential risk factors affecting individuals with chronic pain (8). Although it is stated in the literature that individuals with chronic pain may be adversely affected during the pandemic, there is no study examining the effects of the pandemic on pain, physical activity and anxiety in this population. Therefore, the aim of this study was to examine the effects of the pandemic on pain, physical activity and anxiety in individuals with chronic musculoskeletal pain, in both periods of isolation and controlled social life.

\section{MATERIAL and METHODS}

\section{Study Design and Participants}

Seventy one individuals with chronic musculoskeletal pain were recruited based on the following inclusion criteria: the ability to speak and comprehend Turkish, being 18 years of age or older and ongoing musculoskeletal pain for at least 3 months. Individuals with acute pain, cancer, osteoporosis and rheumatologic diseases were excluded from the study ${ }^{(9)}$.

Three different periods were evaluated and analyzed:

i. Pre-pandemic period: The participants were asked to respond retrospectively considering the period before the COVID-19 pandemic.

ii. Isolation period: The lockdown period in which face-to-face treatments were postponed or canceled. The participants were asked to respond retrospectively (considering March, April and May 2020).

iii. Controlled social life period: The period of gradual deconfinement in which face-to-face treatment sessions were resumed (starting from $1^{\text {st }}$ June).

This study was approved by local ethics committee (approval number=02 and date 29.06.2020). All participants provided written consent to participate in the study in accordance with the Helsinki Declaration.

\section{Outcome Measures}

Clinical characteristics and demographic data and of the participants were collected.

\section{Pain Assessment}

To evaluate pain intensity, the Visual Analogue Scale (VAS) was used. The scale is consisted of a $10 \mathrm{~cm}$ line, the two endpoints of which represent " $0=$ no pain" and "10 = the most intense pain". The patients were asked to mark the line on any point that corresponded to their pain intensity. For each participant, the distance between their marked point and " 0 " was measured and recorded (10). 


\section{Coronavirus Anxiety Scale Short Form (CAS-SF)}

As a brief mental health screener, the CAS-SF identifies any potential dysfunctional anxiety in relation with the COVID-19 pandemic. A 5-point "Likert scale" is used to document the frequency of the sypmtoms over the last two weeks. The responses range from 0 (never) to 4 (almost every day). The total score (ranging from 0 to 20 ) is calculated by suming the score of each item. Higher scores indicate higher anxiety levels ${ }^{(11)}$. The validity and reliablity of the Turkish version of the CAS-SF is already reported ${ }^{(12)}$.

\section{International Physical Activity Questionnaire Short Form (IPAQ-SF)}

The level of PA was measured using the IPAQ-SF, which consists of scores for vigorous activities, moderate activities, and walking that are calculated as durations multiplied by known metabolic equivalents (MET) per activity. The score for the question about sitting (physical inactivity) is a separate score and is not included in the PA total score ${ }^{(13)}$. The validity and reliablity of the Turkish version of the IPAQ-SF is already reported ${ }^{(14)}$.

\section{Sample Size}

To the best of our knowledge, there is no study investigating pain, physical activity and anxiety in individuals with chronic musculoskeletal pain before and during COVID-19 pandemic (during isolation and controlled social life periods). However, a previous study reported that weekly walking time decreased due to the pandemic (walking time before the pandemic: $37.2 \pm 46.8 \mathrm{~min} /$ week; during the pandemic: $24.6 \pm 34.1 \mathrm{~min} /$ week) ${ }^{(15)}$. Based on this study, the minimum required sample size was calculated as 70 participants for the effect size of 0.300 , the probability level of 0.05 , and the statistical power level of $80 \%$ using G*Power Software (ver. 3.1.9.2, Düsseldorf, Germany).

\section{Data Analysis}

The IBM $^{\circledR}$ SPSS $^{\circledast}$ Statistics for Windows software (Version 20.0. Armonk, NY: IBM Corp.) was used to analyse the data. Normality was checked using Shapiro-Wilk test and histograms. "Repeated measures analysis of variance with Bonferroni correction" was used to evaluate whether there was a difference between pain and physical activity in pre-pandemic, isolation and controlled social life periods. Paired sample t test was used to evaluate whether there was a difference in anxiety during periods of isolation and controlled social life.

\section{RESULTS}

A total of 71 individuals with chronic musculoskeletal pain participated in the study. The mean age was $50.04 \pm 13.14$ years and $74.6 \%$ of the participants were women. Demographic and clinical data of the participants is presented in Table 1.

Table 1. Characteristics of the participants.

\begin{tabular}{|c|c|}
\hline Variables $(n=71)$ & Mean \pm SD \\
\hline Age (years) & $50.04 \pm 13.14$ \\
\hline Sex, female (n, (\%)) & $53(74.6)$ \\
\hline Height $(\mathrm{cm})$ & $164.85 \pm 6.75$ \\
\hline Weight (kg) & $76.36 \pm 11.81$ \\
\hline Body mass index $\left(\mathrm{kg} / \mathrm{m}^{2}\right)$ & $28.14 \pm 4.37$ \\
\hline \multicolumn{2}{|l|}{ Education } \\
\hline University (n, (\%)) & 14 (19.7) \\
\hline High school (n, (\%)) & $17(23.9)$ \\
\hline Secondary school (n, (\%)) & $1(1.4)$ \\
\hline Primary school (n, (\%)) & 39 (54.9) \\
\hline \multicolumn{2}{|l|}{ Pain Location } \\
\hline Low back (n, (\%)) & $24(33.8)$ \\
\hline Shoulder (n, (\%)) & $22(31.0)$ \\
\hline Knee $(n,(\%))$ & $10(14.1)$ \\
\hline $\operatorname{Neck}(n,(\%))$ & $6(8.5)$ \\
\hline Hand $(n,(\%))$ & $5(7.0)$ \\
\hline Elbow (n, (\%)) & $3(4.2)$ \\
\hline Foot $(n,(\%))$ & $1(1.4)$ \\
\hline
\end{tabular}




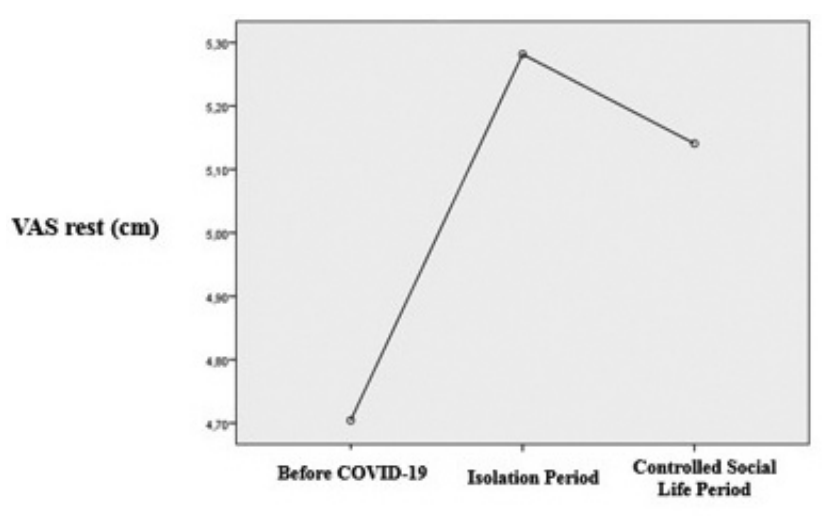

a

Figure 1. Comparison of pain intensity.

The changes over time in VAS at rest $(p=.001)$ and VAS during activity $(p<.001)$ were statistically significant (Table 2, Figure 1). The VAS resting score was significantly higher during the isolation compared to the pre-pandemic period $(p=.002$, Table 2$)$. The VAS activity score was significantly higher in the isolation period compared to both pre-pandemic ( $p$ $<.001)$ and controlled social life periods $(p<.001$, Table 2).

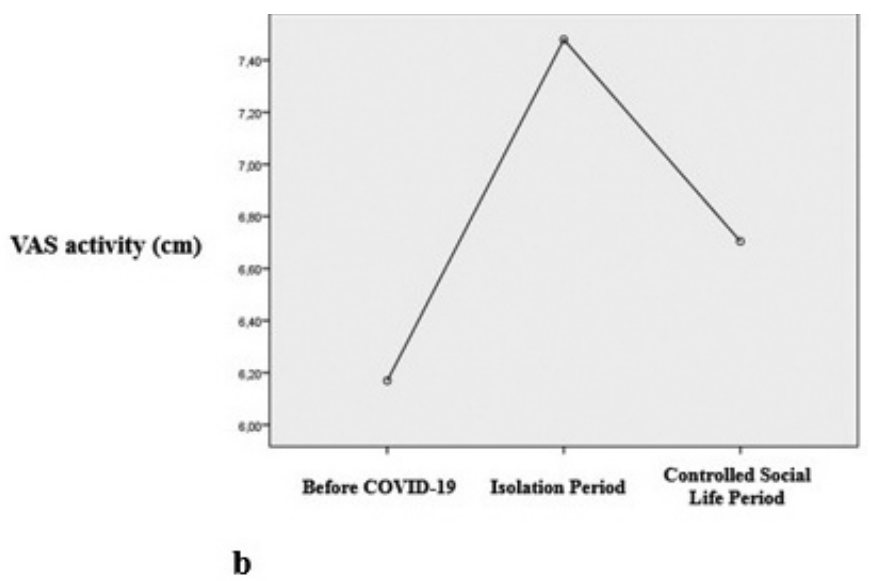

The changes over time in IPAQ-SF scores $(p<.001)$ and sitting time $(p<.001)$ were also statistically significant (Table 2, Figure 2). The lowest IPAQ-SF score $(p<.001)$ and the longest sitting time $(p<.001)$ were in the isolation period (Table 2).

The CAS-SF scores were significantly higher in the isolation period compared to the controlled social life period $(p<.001$, Table 2$)$.

Table 2. Comparison of outcomes.

\begin{tabular}{|c|c|c|c|c|c|c|c|}
\hline & \multirow{2}{*}{$\begin{array}{l}\text { Before COVID-19 } \\
\text { (1) }\end{array}$} & \multirow{2}{*}{$\begin{array}{l}\text { Isolation Period } \\
\text { (2) }\end{array}$} & \multirow{2}{*}{$\begin{array}{l}\text { Controlled Social Life } \\
\quad \text { Period (3) }\end{array}$} & \multirow{2}{*}{$\begin{array}{c}\text { Pairwise } \\
\text { Comparisons }\end{array}$} & \multirow{2}{*}{$\mathbf{p}^{1}$ value } & \multicolumn{2}{|c|}{ Time } \\
\hline & & & & & & $\frac{p^{2} \text { value }}{4}$ & Partial Eta Squared \\
\hline \multicolumn{8}{|l|}{ Pain Intensity } \\
\hline \multirow{3}{*}{ VAS rest $(\mathrm{cm})$} & \multirow{3}{*}{$4.70 \pm 1.3$} & \multirow{3}{*}{$5.28 \pm 1.14$} & \multirow{3}{*}{$5.14 \pm 1.07$} & $1-2$ & .002 & \multirow{3}{*}{.001} & \multirow{3}{*}{120} \\
\hline & & & & $1-3$ & .027 & & \\
\hline & & & & $2-3$ & .175 & & \\
\hline \multirow{3}{*}{ VAS activity $(\mathrm{cm})$} & \multirow{3}{*}{$6.16 \pm 1.6$} & \multirow{3}{*}{$7.47 \pm 1.4$} & \multirow{3}{*}{$6.70 \pm 1.2$} & $1-2$ & $<.001$ & \multirow{3}{*}{$<.001$} & \multirow{3}{*}{.251} \\
\hline & & & & $1-3$ & .059 & & \\
\hline & & & & $2-3$ & $<.001$ & & \\
\hline \multicolumn{8}{|l|}{ Physical Activity } \\
\hline \multirow{3}{*}{$\begin{array}{c}\text { IPAQ-SF } \\
\text { (MET min/wk) }\end{array}$} & \multirow{3}{*}{$1002.14 \pm 549.7$} & \multirow{3}{*}{$234.95 \pm 211.1$} & \multirow{3}{*}{$750.13 \pm 410.1$} & $1-2$ & $<.001$ & \multirow{3}{*}{$<.001$} & \multirow{3}{*}{.551} \\
\hline & & & & 1-3 & $<.001$ & & \\
\hline & & & & $2-3$ & $<.001$ & & \\
\hline \multirow{3}{*}{ Sitting time (min/day) } & \multirow{3}{*}{$194.92 \pm 36.3$} & \multirow{3}{*}{$369.50 \pm 56.8$} & \multirow{3}{*}{$222.81 \pm 56.4$} & $1-2$ & $<.001$ & \multirow{3}{*}{$<.001$} & \multirow{3}{*}{.916} \\
\hline & & & & $1-3$ & $<.001$ & & \\
\hline & & & & $2-3$ & $<.001$ & & \\
\hline \multicolumn{8}{|l|}{ CAS-SF } \\
\hline CAS-SF score $(0-20)$ & N/A & $7.61 \pm 2.9$ & $5.12 \pm 3.3$ & N/A & $<.001^{*}$ & N/A & N/A \\
\hline
\end{tabular}

Notes: $p 1=$ Adjustment for multiple comparisons: Bonferroni; $p 2=$ Repeated measures analysis of variance; *: Paired sample t test. Values are expressed as mean \pm standard deviation Abbreviations: VAS: Visual Analogue Scale, IPAQ-SF: International Physical Activity Questionnaire Short Form, N/A: Not applicable 


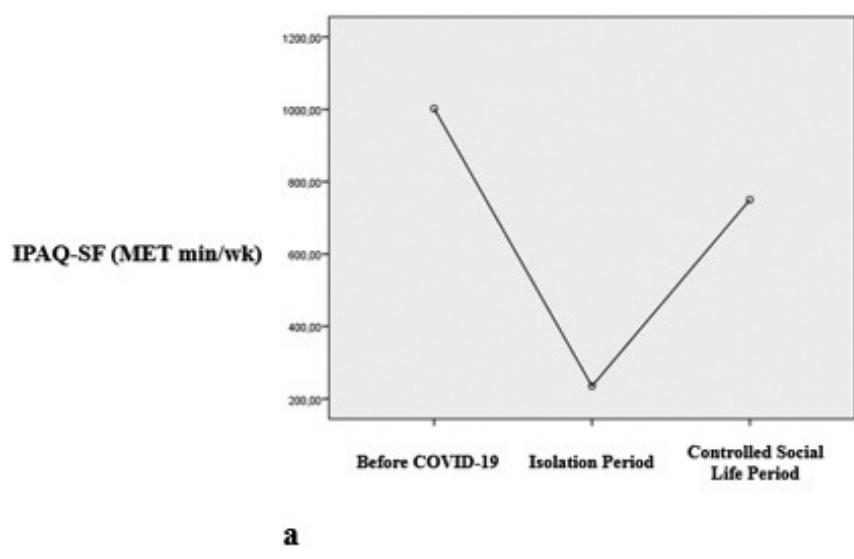

Figure 2. Comparison of physical activity.

\section{DISCUSSION}

The present study is the first in the literature investigating the effects of COVID-19 pandemic (including both isolation and controlled social life periods) on pain, physical activity, and anxiety in individuals with chronic musculoskeletal pain. The main finding of the study was that during the isolation period the pain intensity of the participants was the highest and their physical activity level was the lowest. In addition, anxiety was higher during the isolation period compared to the controlled social life period.

The COVID-19 crisis has adversely influenced healthcare sector including healthcare professionals and patients ${ }^{(16)}$. Several measures such as social distancing and reorganizing the priorities in delivering health services are implemented to control the spread of the virus ${ }^{(17)}$. The undesirable effects on the healthcare system and social life are likely to increase the likelihood for chronic pain symptoms to worsen (16). Indeed, our findings indicated that individuals with chronic musculoskeletal pain had the highest level of pain during the isolation period, which decreased in controlled social life period. It is thought that difficulties in accessing health services, physical inactivity and increased anxiety level might be the reasons for the highest level of pain during the isolation.

During the pandemic, the level of physical activity

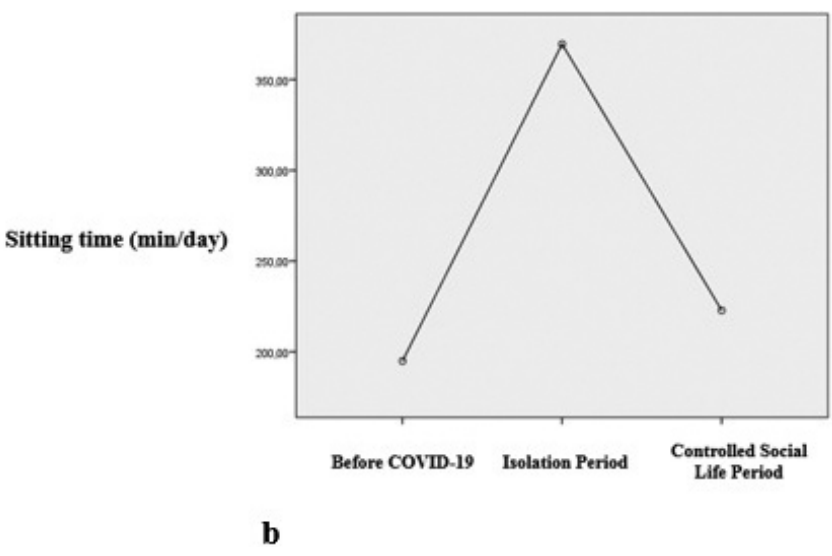

has decreased due to the measures taken in many countries ${ }^{(18)}$. The cardiovascular system and many other biological systems and structures are adversely affected as a result of physical inactivity ${ }^{(19)}$. It is also known that decreased physical activity is a risk factor for increased chronic pain severity ${ }^{(20)}$. In line with previous studies reporting reduced levels of physical activity during the COVID-19 pandemic, our study concluded that physical activity decreased and sitting time increased during the pandemic indicating that individuals with chronic musculoskeletal pain may experience higher levels of pain severity due to physical inactivity.

The psychological effects of the pandemic can be as notable as its physical impact ${ }^{(21)}$. It is reported that the COVID-19 pandemic can lead to higher levels of anxiety and depression ${ }^{(22)}$. This constitutes a risk factor especially for patients with chronic pain ${ }^{(8)}$. According to our findings, anxiety level was high during the isolation and decreased in the controlled social life period. In other words, anxiety was the highest in the isolation period, during which the severity of pain was also the highest.

The study has some limitations that need to be addressed. First is the fact that our sample consisted of patients with chronic musculoskeletal pain; whereas, including a control group of healthy individuals could be more effective in showing the effects of physical activity and changes in anxiety levels. The second limitation is that the effect of the 
location of pain on physical activity and anxiety of the participants was not examined. Depending on the location of pain, potential differences could affect the results. Lastly, categorizing the participants' age in intervals of decades could increase the overall availability and generalization of the results.

\section{CONCLUSION}

While the measures taken during the isolation period had negative impacts on the severity of pain, physical activity, and anxiety levels in individuals with chronic musculoskeletal pain, gradual deconfinement in the controlled social life period led to a decrease in pain intensity and anxiety and an increase in physical activity. These results highlight the importance of the efficient management of the pandemic period for individuals with chronic musculoskeletal pain. Developing programs aimed at increasing physical activity and reducing anxiety in individuals with chronic musculoskeletal pain can be effective in pain management.

Ethics Committee Approval: This study was approved by the ethics committee of the University of Health Sciences Izmir Bozyaka Education and Research Hospital (approval number $=02$ and date 29/06/2020).

Conflict of Interest: No conflict of interest was declared by the authors.

Funding: The authors declared that this study received no financial support.

Informed Consent: All the participants provided written informed consent to participate in the study.

\section{REFERENCES}

1. Gharaei H, Diwan S. COVID-19 Pandemic: Implications on Interventional Pain Practice-a Narrative Review. Pain Physician. 2020;23(4s):S311-s8. [CrossRef]

2. Shanthanna H, Strand NH, Provenzano DA, Lobo CA, Eldabe $S$, Bhatia $A$, et al. Caring for patients with pain during the COVID-19 pandemic: consensus recommendations from an international expert panel. Anaesthesia. 2020;75(7):935-44. [CrossRef]
3. Deer TR, Sayed D, Pope JE, Chakravarthy KV, Petersen E, Moeschler SM, et al. Emergence From the COVID-19 Pandemic and the Care of Chronic Pain: Guidance for the Interventionalist. Anesth Analg. 2020;131(2):387-94. [CrossRef]

4. Clauw DJ, Häuser W, Cohen SP, Fitzcharles MA. Considering the potential for an increase in chronic pain after the COVID19 pandemic. Pain. 2020;161(8):1694-7. [CrossRef]

5. Gatchel RJ, Peng YB, Peters ML, Fuchs PN, Turk DC. The biopsychosocial approach to chronic pain: scientific advances and future directions. Psychol Bull. 2007;133(4):581-624. [CrossRef] https://doi.org/10.1037/0033-2909.133.4.581

6. Afari N, Ahumada SM, Wright LJ, Mostoufi S, Golnari G, Reis $V$, et al. Psychological trauma and functional somatic syndromes: a systematic review and meta-analysis. Psychosom Med. 2014;76(1):2-11. [CrossRef]

7. Crettaz B, Marziniak M, Willeke P, Young P, Hellhammer D, Stumpf $A$, et al. Stress-induced allodynia--evidence of increased pain sensitivity in healthy humans and patients with chronic pain after experimentally induced psychosocial stress. PLoS One. 2013;8(8):e69460. [CrossRef]

8. Kemp HI, Corner E, Colvin LA. Chronic pain after COVID-19: implications for rehabilitation. Br J Anaesth. 2020;125(4):43640. [CrossRef]

9. Gerdle B, Ghafouri B, Ernberg M, Larsson B. Chronic musculoskeletal pain: review of mechanisms and biochemical biomarkers as assessed by the microdialysis technique. J Pain Res. 2014;7:313-26. [CrossRef]

10. McCormack HM, Horne DJ, Sheather S. Clinical applications of visual analogue scales: a critical review. Psychol Med. 1988;18(4):1007-19. [CrossRef]

11. Lee SA. Coronavirus Anxiety Scale: A brief mental health screener for COVID-19 related anxiety. Death Stud. 2020;44(7):393-401. [CrossRef]

12. Biçer I, Çakmak C, Demir H, Kurt ME. Coronavirus Anxiety Scale Short Form: Turkish Validity and Reliability Study. Anatol Clin. 2020; 25(Supplement 1):216-25. [CrossRef]

13. Lee PH, Macfarlane DJ, Lam TH, Stewart SM. Validity of the International Physical Activity Questionnaire Short Form (IPAQ-SF): a systematic review. Int J Behav Nutr Phys Act. 2011;8:115. [CrossRef]

14. Saglam M, Arikan H, Savci S, Inal-Ince D, Bosnak-Guclu M, Karabulut $E$, et al. International physical activity questionnaire: reliability and validity of the Turkish version. Percept Mot Skills. 2010;111(1):278-84. [CrossRef]

15. Ammar A, Brach M, Trabelsi K, Chtourou H, Boukhris $O$, Masmoudi L, et al. Effects of COVID-19 Home Confinement on Eating Behaviour and Physical Activity: Results of the ECLB-COVID19 International Online Survey. Nutrients. 2020;12(6).

16. Javed S, Hung J, Huh BK. Impact of COVID-19 on chronic pain patients: a pain physician's perspective. Pain Manag. 2020;10(5):275-7. [CrossRef]

17. Puntillo F, Giglio M, Brienza N, Viswanath O, Urits I, Kaye AD, et al. Impact of COVID-19 pandemic on chronic pain management: Looking for the best way to deliver care. Best Pract Res Clin Anaesthesiol. 2020;34(3):529-37. [CrossRef]

18. Lesser IA, Nienhuis CP. The Impact of COVID-19 on Physical Activity Behavior and Well-Being of Canadians. Int J Environ Res Public Health. 2020;17(11). [CrossRef]

19. Peçanha T, Goessler KF, Roschel H, Gualano B. Social isolation during the COVID-19 pandemic can increase physical inactivity and the global burden of cardiovascular disease. 
G. Özsoy ve ark., The Effeck of COVID-19 Pandemic on Pain, Physical Activity, and Anxiety in Individuals with Chronoic Musculoskeletal Pain

Am J Physiol Heart Circ Physiol. 2020;318(6):H1441-h6. [CrossRef]

20. Geneen LJ, Moore RA, Clarke C, Martin D, Colvin LA, Smith $\mathrm{BH}$. Physical activity and exercise for chronic pain in adults: an overview of Cochrane Reviews. Cochrane Database Syst Rev. 2017;1(1):Cd011279. [CrossRef]
21. Vindegaard N, Benros ME. COVID-19 pandemic and mental health consequences: Systematic review of the current evidence. Brain Behav Immun. 2020;89:531-42. [CrossRef]

22. Tang F, Liang J, Zhang H, Kelifa MM, He Q, Wang P. COVID-19 related depression and anxiety among quarantined respondents. Psychology \& Health. 2020:1-15. [CrossRef] 